\title{
THE INFLUENCE OF MARITAL STATUS ON EPIDEMIOLOGICAL CHARACTERISTICS OF SUICIDES IN THE SOUTHEASTERN PART OF SERBIA
}

\author{
Branislav Petrović1, Biljana Kocić1, Dragana Nikić1, Maja Nikolić1, Dragan Bogdanović \\ ${ }^{1}$ Public Health Institute Niš, University of Niš Medical School, Serbia \\ ${ }^{2}$ Public Health Institute Niš, Serbia
}

\section{SUMMARY}

Background: The support of close persons is a protective factor in the suicide epidemiology. The aim of this paper is to determine if there are differences between epidemiological characteristics of the suicides committed by married people in relation to singles.

Methods: In order to determine epidemiological characteristics of suicide among married and single people in the southeastern Serbia 628 suicides committed from 1995 to 2002 among persons 20 years of age and over were analysed. To compare suicide rates between married and single persons $x^{2}$ test was performed.

Results: From 628 registered suicides, 188 were performed by women, and 440 by men. The average annual suicide rate among males was 24.1 per 100,000 and among females it was 9.9. The highest rates were among widowed (139.0) and divorced men (63.2). The highest risk factor for suicide was to be widowed (men: $R R=8.35$; women: $R R=2.75$ ). The suicide trend among women, both married and single has been declining, whilst among males it has been on significant increase. Seasonality of suicides, weekly and daily distribution had a small influence on the epidemiological characteristics of suicides. Married women committed more suicides by poisoning than single women $(p=0.02)$. In both groups, the most frequent way is hanging.

Conclusion: Though marital status plays important role in an increasing rates of suicide, time and the way of its happening, this role is not decisive. Single people are very vulnerable and the time and way of suicide show that their reasons are more serious than among married ones.

Key words: suicide, epidemiology, marital status, hanging, poisoning, firearms

Address for correspondence: D. Bogdanović, Institut za javno zdravlje Niš, Bulevar Zorana Djindjića 50, 18000 Niš, Srbija.

E-mail: draganbogdanovic@gmail.com

\section{INTRODUCTION}

According to the recent World Health Organization's news, there are 815,000/year suicides registered in the world (1), which is less than million suicides a year reported previously $(2,3)$. Studies of suicide risk factors have had difficulty in determing what risk factors could easily identify people at risk to make prevention programmes more focused and effective (4). Although most suicide factors are discovered, the reason for this dramatic act is still unknown to everyone, except the suicide. Scientifically, there has been an improvement in understanding this phenomenon, and many risk factors for suicide have been determined. The support of close persons (friend, spouse) is a protective factor in the suicide epidemiology $(5,6)$, and, therefore, one could assume that epidemiological characteristics of suicides between married and single people are different.

\section{METHODS}

The aim of this paper is to analyse eventual differences in basic epidemiological characteristics of suicide in the southeastern Serbia according to the marital status.
Suicides were identified by the International Classification of Diseases (ICD-10) X-60 to X-84. In order to determine epidemiological characteristics of suicide among married and single (unmarried, divorced and widowed) people in the southeastern Serbia (Nisava, Toplica and Pirot district), all the cause-of-death certificates for each person that committed suicide from 1995 to 2002 were reviewed. A total of 628 cases were reported as suicides among persons 20 years of age and over during the investigated period. The cause-of-death certificates (the original documents, individual death certificates, made and signed by doctors who had stated the diagnoses of deaths) were collected in the Regional Statistic Centre in Niš. The rates were calculated per 100,000 inhabitants according to the estimation of the yearly number population, based on 1991 and 2002 censuses. The standard statistical parameters usually used in descriptive epidemiology were applied (rates, relative risks, 95\% confidence interval and $\chi^{2}$ test). All statistics calculations were done in the Excel 97, and Epi info 5.0 software programmes and statistical significance was determined on $\mathrm{p}<0.05$ level. Unfortunately, there are no data about population according to marital status for southeastern Serbia. The number of persons in the southeastern Serbia according to marital status has been estimated based on the results of large investigation performed in Serbia in 2000 (7). This investigation pointed out that in Serbia among population 
aged 20 years and over there were: $67.7 \%$ married women and $78.9 \%$ married men; $17 \%$ widowed women and $3.9 \%$ widowed men; $5.4 \%$ (women) and 2.6 (men) divorced; $10 \%$ (women) and $14.6 \%$ (men) unmarried. Suicide rates and relative risks in our paper were estimated for people 20 years of age and over with known marital status ( $\mathrm{n}=628$ individuals).

\section{RESULTS}

In the period from 1995 to 2002 , in the territory of the southeastern Serbia, there were 628 registered suicides, out of which 188 were performed by women and 440 by men. The average annual rate of the suicides among men was 24.1 and among women it was 9.9, which is 2.4 times less than among men.

The breakdown of suicides by marital status is given in Table 1. The greatest proportion of the people who committed suicide was married (54.5\% among men and 50.0\% among women) and widowed (22.3\% among men, and $34.5 \%$ among women). The average annual suicide rate regardless sex was 16.9 per 100,000 inhabitants. The average annual rate among persons without marital partner (29.4) was 2.4 times higher than among married persons (12.3). The highest rates were observed among widowed (males - 139.0; females - 20.2), divorced (males - 63.2; females -10.7) and unmarried (males - 26.6; females -9.5) and the least among married persons (males - 16.7; females -7.3 ).

Table 1. Total number of suicides and average annual rates related to marital status among persons 20 years of age and over in the southeastern Serbia from 1995 to 2002

\begin{tabular}{|l|c|c|c|c|}
\hline Marital status & $\begin{array}{c}\text { Estimated } \\
\text { popula- } \\
\text { tion }\end{array}$ & $\begin{array}{c}\text { Number } \\
\text { of sui- } \\
\text { cides }\end{array}$ & $\%$ & $\begin{array}{c}1 / 100 \text { 000 } \\
\text { average } \\
\text { annual } \\
\text { rates }\end{array}$ \\
\hline Males & 228,260 & 440 & 100.0 & 24.1 \\
\hline total & 180,097 & 240 & 54.5 & 16.7 \\
\hline married & 48,163 & 200 & 45.5 & 51.9 \\
\hline $\begin{array}{l}\text { without marital } \\
\text { partner }\end{array}$ & 8,902 & 99 & 22.3 & 139.0 \\
\hline widowed & 5,934 & 30 & 5.7 & 63.2 \\
\hline divorced & 33,325 & 71 & 17.5 & 26.6 \\
\hline bachelors & 237,071 & 188 & 100.0 & 9.9 \\
\hline Females & 160,259 & 94 & 50.0 & 7.3 \\
\hline total & 76,812 & 94 & 50.0 & 15.3 \\
\hline married & 40,302 & 65 & 34.5 & 20.2 \\
\hline $\begin{array}{l}\text { without marital } \\
\text { partner }\end{array}$ & 12,801 & 11 & 5.8 & 10.7 \\
\hline widowed & 23,707 & 18 & 9.6 & 9.5 \\
\hline divorced & 465,331 & 628 & 100.0 & 16.9 \\
\hline unmarried & 340,356 & 334 & 53.2 & 12.2 \\
\hline $\begin{array}{l}\text { TOTAL (Males and } \\
\text { Females) }\end{array}$ & 124,975 & 294 & 46.8 & 27.8 \\
\hline married & $\begin{array}{c}\text { without marital } \\
\text { partner }\end{array}$ & & & \\
\hline
\end{tabular}

To be married is protective factor for suicide [males: relative risk $(\mathrm{RR})=0.32 ; 95 \%$ confidence interval $(\mathrm{CI})=0.26-0.39$; $\mathrm{p}=0.0000$; females: $\mathrm{RR}=0.48$; 95\%CI:0.36-0.64; $\mathrm{p}=0.0000]$.

Relative risks for suicide among single persons in relation to married ones are shown in Table 2. Between the both genders, living without marital partner is a risk factor for suicide (males: $R R=3.21$; females: $R R=2.01$ ), which is more significant for men. The most important risk factor for men's suicide is to be widowed $(\mathrm{RR}=8.35)$, followed by divorce $(\mathrm{RR}=3.79)$ and bachelor status $(\mathrm{RR}=1.60)$. Among women statistically important risk factor is to be widowed $(\mathrm{RR}=2.75)$, while to be divorced and unmarried has no great influence on suicide risk.

Table 2. Marital status as a risk factor for suicide among persons 20 years of age and over in southeastern Serbia

\begin{tabular}{|l|c|c|c|c|}
\hline Marital status & $\mathbf{R R}^{*}$ & $95 \% \mathbf{C l}$ & $\mathbf{X}^{2}$ & $\mathbf{p}$ \\
\hline Males & & & & \\
\hline married & 1.00 & & & \\
\hline $\begin{array}{l}\text { without marital } \\
\text { partner }\end{array}$ & 3.21 & $2.57-3.78$ & 156.22 & 0.0000 \\
\hline widowed & 8.35 & $6.55-10.62$ & 448.35 & 0.0000 \\
\hline divorced & 3.79 & $2.54-5.63$ & 54.59 & 0.0000 \\
\hline bachelors & 1.60 & $1.22-2.10$ & 12.26 & 0.0005 \\
\hline $\begin{array}{l}\text { Females } \\
\text { maried }\end{array}$ & 1.00 & & & \\
\hline $\begin{array}{l}\text { without marital } \\
\text { partner }\end{array}$ & 2.01 & $1.49-2.70$ & 23.76 & 0.0000 \\
\hline widowed & 2.75 & $1.98-3.82$ & 42.72 & 0.0000 \\
\hline divorced & 1.47 & $0.74-2.82$ & 1.45 & 0.2281 \\
\hline unmaried & 1.29 & $0.76-2.19$ & 1.01 & 0.3146 \\
\hline
\end{tabular}

* versus to married

\section{Epidemiological Characteristics of Suicide among Women}

1. Suicide trend. In the observed period, the suicide trend among married women, as well as among those living alone was in decline (Fig 1). However, a somewhat greater decline was registered among women living alone $(\mathrm{Y}=-0.1429 \mathrm{x}+12.393$; $\left.\mathrm{R}^{2}=0.0173\right)$ than among the married ones $(\mathrm{Y}=-0.0476 \mathrm{x}+12.214$; $\mathrm{R}^{2}=0.008$ ). The average annual suicide rates among females in 1995-1998 (married: 7.5; single: 15.9) slightly declined in 1999-2002 (married: 7.2; single:14.6). Single women committed more suicides than married women in 1995 and 2001.

2. Seasonality of suicides. Between both these groups of women, the seasonal distribution of suicides was almost identical: suicides were most frequently committed in spring and summer. Among married women, the least number of suicides was committed during the winter, and among those living without a marital partner it was in autumn. Women without a spouse committed suicide more often than married women in winter and autumn (Table 3), but this difference is not statistically important.

3. Weekly suicide distribution. Polynomial trends show that among single women, the maximum number of suicides takes place on Saturdays, Fridays and Mondays that is immediately before or during the weekends, and among married women on Tuesdays, Saturdays and Sundays but these differences are, gen- 


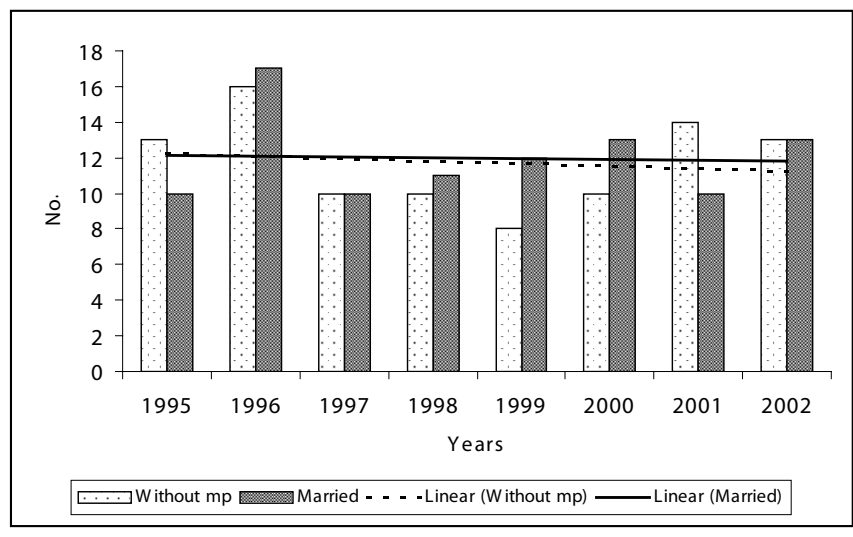

Fig. 1. Trend of female suicide number in the southeastern Serbia from 1995 to 2002 ( $m p=$ marital partner).

erally statistically insignificant (Table 3 ). There is a statistically significant difference in the number of committed suicides on
Thursdays and Fridays: on Thursdays suicides were more frequent among married women $\left(\chi^{2}=3.83, \mathrm{DF}=1, \mathrm{p}=0.0473\right)$, and among single women on Fridays $\left(\chi^{2}=6.43, \mathrm{DF}=1, \mathrm{p}=0.0112\right)$.

4. Daily distribution of suicides. In relation to the periods of the day, there were no statistically significant differences between single and married women. Most frequently suicides happen between 6.00 AM and 6.00 PM (Table 3). Women without a spouse more frequently commit suicides in the early morning hours $(0.00-5.59 \mathrm{AM})$.

5. The way of committing suicide. There is a statistically significant difference in the ways of committing suicides between single and married women (Table 3 ). Married women commit more suicides by poisoning than single women $\left(\chi^{2}=6.65\right.$; $\mathrm{p}=0.0099$ ).

\section{Epidemiological Characteristics of Suicide among Men}

1. Suicide trend. In the observed period, the trend of suicides among males is significantly increased (Fig. 2), with the increase

Table 3. Epidemiological characteristic of suicide acorrding to marrital status

\begin{tabular}{|c|c|c|c|c|c|c|c|c|c|c|c|c|}
\hline & \multicolumn{6}{|c|}{ Females } & \multicolumn{6}{|c|}{ Males } \\
\hline & $\begin{array}{c}\text { Without } \\
\mathrm{mp}\end{array}$ & $\%$ & $95 \% \mathrm{Cl}$ & Married & $\%$ & $95 \% \mathrm{Cl}$ & $\begin{array}{c}\text { Without } \\
\mathrm{mp}\end{array}$ & $\%$ & $95 \% \mathrm{Cl}$ & Married & $\%$ & $95 \% \mathrm{Cl}$ \\
\hline \multicolumn{13}{|c|}{ Seasonal distribution of suicide } \\
\hline |-||| & 23 & 24.5 & $15.8-33.2$ & 13 & 13.8 & $6.8-20.8$ & 39 & 19.5 & $14.0-25.0$ & 44 & 18.3 & $13.4-23.2$ \\
\hline $\mid \mathrm{V}-\mathrm{VI}$ & 26 & 27.7 & $18.7-36.7$ & 32 & 34.0 & $24.4-43.6$ & 62 & 31.0 & $24.6-37.4$ & 69 & 28.7 & $23.0-34.4$ \\
\hline VIIIIX & 26 & 27.7 & $18.7-36.7$ & 32 & 34.0 & $24.4-43.6$ & 61 & 30.5 & $24.1-36.9$ & 73 & 30.4 & $24.5-36.3$ \\
\hline$X-X \|$ & 19 & 20.2 & $12.1-28.3$ & 17 & 18.1 & $10.3-25.9$ & 38 & 19.0 & $13.6-24.4$ & 54 & 22.5 & $17.2-27.8$ \\
\hline \multicolumn{13}{|c|}{ Weekly distribution of suicide } \\
\hline Mon & 15 & 16.0 & $8.6-23.4$ & 13 & 13.8 & $6.8-20.8$ & 33 & 16.5 & $11.4-21.6$ & 31 & 12.9 & $8.7-17.1$ \\
\hline Tue & 10 & 10.6 & $4.4-16.8$ & 18 & 19.1 & $11.1-27.1$ & 27 & 13.5 & $8.8-18.2$ & 40 & 16.7 & $12.0-21.4$ \\
\hline Wed & 13 & 13.8 & $6.8-20.8$ & 13 & 13.8 & $6.8-20.8$ & 31 & 15.5 & $10.5-20.5$ & 25 & 10.4 & $6.5-14.3$ \\
\hline Thy & $5^{*}$ & 5.3 & $0.8-9.8$ & 13 & 13.8 & $6.8-20.8$ & 26 & 13.0 & $8.3-17.7$ & 42 & 17.5 & $12.7-22.3$ \\
\hline Fri & $19 \dagger$ & 20.2 & $12.1-28.3$ & 7 & $7.4^{*}$ & $2.1-12.7$ & 33 & 16.5 & $11.4-21.6$ & 29 & 12.1 & $8.0-16.2$ \\
\hline Sat & 20 & 21.3 & $13.0-29.6$ & 16 & 17.0 & $9.4-24.6$ & 25 & 12.5 & $7.9-17.1$ & 32 & 13.3 & $9.0-17.6$ \\
\hline Sun & 12 & 12.8 & $6.0-19.6$ & 14 & 14.9 & $7.7-22.1$ & 25 & 12.5 & 7.9-17.1 & 41 & 17.1 & $12.3-21.9$ \\
\hline \multicolumn{13}{|c|}{ Daily distribution of suicide } \\
\hline $0.00-5.59$ & 14 & 14.9 & $7.7-22.1$ & 9 & 9.6 & $3.7-15.5$ & 32 & 16.0 & $10.9-21.1$ & 31 & 12.9 & $8.7-17.1$ \\
\hline $6.00-11.59$ & 23 & 24.5 & $15.8-33.2$ & 29 & 30.6 & $21.3-39.9$ & $37 \ddagger$ & 18.5 & $13.1-23.9$ & 66 & 27.5 & $21.9-33.1$ \\
\hline $12.00-17.59$ & 17 & 18.1 & $10.3-25.9$ & 21 & 22.3 & $13.9-30.7$ & 45 & 22.5 & $16.7-28.3$ & 54 & 22.5 & $17.2-27.8$ \\
\hline $18.00-23.59$ & 9 & 9.6 & $3.6-15.6$ & 12 & 22.8 & $6.0-19.6$ & $26 \ddagger$ & 13.0 & $8.3-17.7$ & 16 & 6.7 & $3.5-9.9$ \\
\hline Unknown & 31 & 33.0 & $23.5-42.5$ & 23 & 24.5 & $15.8-33.2$ & 60 & 30.0 & $23.7-36.3$ & 73 & 30.4 & $24.6-36.2$ \\
\hline \multicolumn{13}{|c|}{ The way of suicide } \\
\hline Hanging & 47 & 50.0 & $39.9-60.1$ & 44 & 46.8 & $36.7-56.9$ & 108 & 54.0 & $47.1-60.9$ & 127 & 52.9 & $46.6-59.2$ \\
\hline Drowning & 14 & 14.9 & $7.7-22.1$ & 7 & 7.4 & $2.1-12.7$ & 6 & 3.0 & $0.6-5.4$ & 9 & 3.7 & $1.3-6.1$ \\
\hline Poisoning & $19 \ddagger$ & 20.2 & $12.1-28.3$ & 35 & 37.2 & $27.4-47.0$ & 17 & 8.5 & $4.6-12.4$ & 28 & 11.7 & $7.6-15.8$ \\
\hline V. scisum & 0 & 0.0 & & 2 & 2.1 & $0-5.0$ & 3 & 1.5 & $0.0-3.2$ & 3 & 1.3 & $0.0-2.7$ \\
\hline Fire arms & 1 & 1.1 & $0.0-3.3$ & 0 & 0.0 & & 31 & 15.5 & $10.5-20.5$ & 29 & 12.1 & $8.0-16.2$ \\
\hline Polytrauma & 6 & 6.4 & $1.5-11.3$ & 4 & 4.3 & $0.2-8.4$ & 12 & 6.0 & $2.7-9.3$ & 6 & 2.5 & $0.5-4.5$ \\
\hline Unknown & 7 & 7.4 & $2.1-12.7$ & 2 & 2.1 & $0-5.0$ & 23 & 11.5 & $7.1-15.9$ & 38 & 15.8 & $11.2-20.4$ \\
\hline
\end{tabular}

NOTES: * $-p<0.05$ vs married; $\dagger-p<0.01$ vs married; $\ddagger-p<0.001$ vs married

$\mathrm{mp}=$ marital partner 


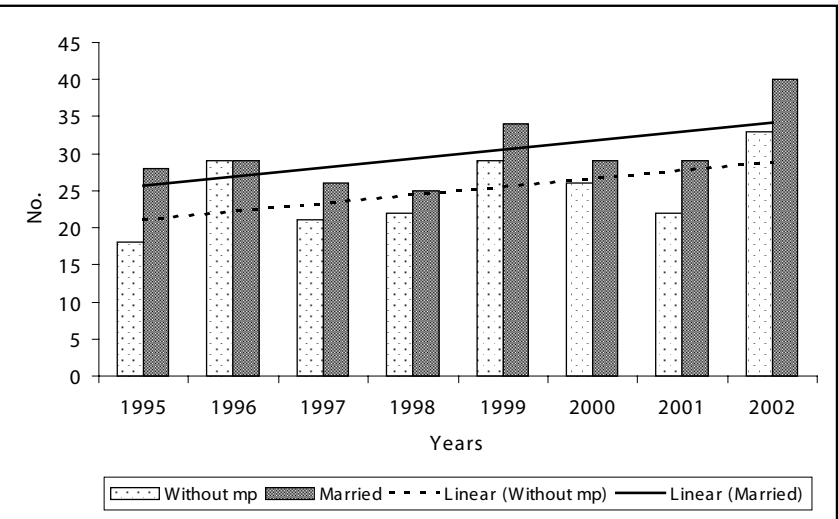

Fig. 2. Trend of male suicide number in the southeastern Serbia from 1995 to 2002 ( $m p=$ marital partner).

higher among married men (married: $Y=1.2143 \mathrm{x}+24.536 ; \mathrm{R}^{2}=0.3776$; single: $\mathrm{Y}=1.0952 \mathrm{x}+20.071 ; \mathrm{R} 2=0.2799)$. The average annual suicide rates among males in 1995-1998 (married: 15.0; single: 56.1) were lower than in 1999-2002 (married: 18.3; single: 58,1)

2. Seasonality of suicide. In both groups, the highest number of suicides took place in spring and summer, while the least number of suicides was committed in winter and autumn. The found out differences were not statistically significant. In these seasons, married men committed more suicides in comparison to those who were single (Table 3 ).

3. Weekly suicide distribution. There is no regular distribution of suicides over the week, especially not among married men. Among single men, from Monday to Sunday, there is a slight decrease of the linear suicide trend, as they commit suicides more often on Mondays, Wednesdays and Fridays, in comparison to the married men. The linear trend among married men grows during the week.

4. Daily suicide distribution. The greatest number of suicides happens in the period between 6.00 AM to 6.00 PM, and the least number between 6.00 PM to $12.00 \mathrm{AM}$ (Table 3). There is a statistically significant difference between the observed groups. Married men commit suicides more often in the period from 6.00 $\mathrm{AM}$ to $12.00 \mathrm{PM}\left(\chi^{2}=4.93 ; \mathrm{DF}=1 ; \mathrm{p}=0.0264\right)$, and even more often between 12.00 PM to 6.00 PM, and single men from 12.00 AM to 6.00 AM and from 6.00 PM to $12.00 \mathrm{AM}\left(\chi^{2}=5.07\right.$; $\mathrm{DF}=1 ; \mathrm{p}=0.0243$ ).

5. The way of committing suicides. There are no statistically significant differences between ways of committing suicides between married and single men. In both groups, the most frequent way is hanging. Single men use more often firearms, or they jump from high buildings, or throw themselves under the means of transportation (polytrauma).

\section{DISCUSSION}

According to the data obtained in this research, the southeastern Serbia can be considered as area of a moderate high suicide rate, among men as well as among women. The similar situation is in some other part of former Yugoslavia (8).

The suicide rates among men are always greater than among women, which can be explained in different ways: men use much more violent (and more lethal) methods of suicide than women (9). According to some research of risk factors for suicides of men, there are protective factors with female population (10). Durkheim et al. showed that maternity is a protective factor for female suicides (11) as did some authors as well (12). This research discovered that the trends of suicides in married and single women is slightly declining, which is in agreement with some other authors (13), and was especially noticed in Great Britain (14, 15). Contrary to women, in some countries in the world (15), as well as in this research, there is an increase of suicides committed by men. The differences between rates of suicide between men and women are explained by changes of social factors (16), as well as by change of role of sex in the modern societies.

Generally speaking, beside the fact that in the large number of countries in the western world there are no national programmes for suicide prevention, there is a certain decline of the suicide trend observed: a decrease of suicide rates is registered not only in countries which had or still have national strategies for suicide prevention (Finland, Sweden, Norway, Denmark), but also in countries in which such programmes do not exist (the Netherlands, Hungary, Malta, Israel) (3). For example, in Denmark and Norway suicide rates among those aged 15 years and over between 1989-1990 and 1995-1996 decreased more than 20\%, and in Malta and Israel about 20\% (17).

Investigations in former Yugoslavia show that suicide rates increased from 1985-1993 (18). According to our earlier investigations conducted in 1987, 1992 and 1997 (19,20,21), the rates of suicide in the Region of Niš increased from 1987-1992, and after that, with some medium oscillation, decreased. The result of the investigation of influence of socio-economics crisis on epidemiological characteristics of suicide in the region of Niš confirm previous results: the rates of suicide during the war activities (March - June 1999) decreased and were lower than average annual rates in 1987/89 among both sexes (22).

According to some investigations, marital status plays important role in the suicide incidence. Suicides are more frequent among persons without marital partner $(23,24,25)$, and one investigation from England had shown that suicide rates among single persons in the last decades decreased, especially among women (26). In this research suicide rates (as well as relative risks) among single men and single women are higher than among married men and women, so to be alone is a certain risk factor for committing suicide. The results of some recent investigations in the world are very close to this one $(5,8,27,28)$. The highest risk factor in men is to be widowed, and than to be divorced and bachelor. Among women the widowhood represents statistically important high risk for suicide, while to be divorced or single is statistically not significant.

In this research, the marital status almost has no role in the fluctuation of the number of suicides in the examined population: within the same sex, the trends of suicides are the same among married and single persons. This finding suggests that marital status is not the decisive risk factor for suicide, and has only contributory role.

There are a great number of researches interested in the seasonality of suicides. Some researches emphasize these characteristics $(29,30,31)$ and some show that this factor has no significance on suicide frequency (32). In our earlier research (21), we discovered that suicides with both men and women are most frequent in spring and at the beginning of summer, but that social-economic circumstances can greatly modify this characteristic. We also 
determined that suicides (regardless of the sex) in both married or single persons, are most frequent in spring and summer, here are no statistically significant differences between them. Single women committed suicides more often than married women in winter and autumn, and single men committed fewer suicides than married man during the whole year.

The weekly suicide distribution shows that, on the whole, there are no statistically significant differences between those who have and those who do not have a partner. However, there is a significant difference among women: married women statistically more often committed suicides on Thursday and single women on Fridays (at the beginning of the weekend). Among married men, the suicide trend grows during the week (from Monday to Sunday), while with single men it falls, although this difference is not statistically significant.

The daily suicide distribution shows that single people of both genders commit more suicides in the early morning hours, while men do it in the evening hours (6,00 PM to 12,00 AM). The statistically significant differences were registered in the male suicides in the period between 6,00 AM to 12,00 PM (single men commit significantly less number of suicides than married men) and between 6,00 PM and 12,00 PM (married men commit less number of suicides than single). The seasonal, weekly and daily distribution of suicides shows that single people are afraid of loneliness, "depressive seasons", the beginning of weekends and morning hours, all of which strengthens the fear of loneliness and contribute to the making a decision about suicide.

Compared to women, men committed suicides by more drastic methods (hanging, with fire arms), and there were no statistically important differences in the way of suicide between married and single men. But, there is a statistically significant difference in the way of suicides between married and single women; that is, married women more often commit suicide by poisoning $(\mathrm{p}=0,02)$. The way of suicide suggests that men are more firm in their decision to commit suicide, while women's suicide is mainly "appeal phenomenon", especially for those who live alone (probability of lethal consequence of poisoning with medicaments is less frequent than poisoning by the other toxic substances).

\section{CONCLUSIONS}

Suicide still represents a big enigma for medical and other sciences (psychology, sociology). Preventive measures have had little, if any, influence on the decline of the suicide rates, even in those countries where prevention is carried out systematically. There are some countries in the world, which have been leading in the suicide rates for the past couple of decades, and there has been a little change in the geographical distribution of suicides in the world. Many factors contribute to suicides, and one of them is, undoubtedly, sex, so that suicides are more frequent among men than among women.

Marital status has important role in the increase of suicide, time of happening and the way, but this role is not decisive. Anyway, single people, especially men, are more vulnerable (depression, fear of loneliness, absence of a close person, etc) than married, so they need special attention when designing preventive activity.

Acknowledgments
The authors are most grateful to Mrs. Zorica Antić (Faculty of Medicine, University of Niš) for translating the paper from Serbian into English.

\section{REFERENCES}

1. World Health Organization. World health report 2001. Geneva: WHO; 2001.

2. World Health Organization. Figures and facts about suicides. Technical report. Geneva: WHO; 1999.

3. De Leo D. Why are we not getting any closer to preventing suicide? $\mathrm{Br}$ J Psychiatry. 2002 Nov; 181:372-4.

4. Mann JJ, Apter A, Bertolote J, Beautrais A, Currier D, Haas A, et al. Suicide prevention strategies: a systematic review. JAMA. 2005 Oct 26;294(16):2064-74.

5. Kposowa AJ. Divorce and suicide risk. J Epidemiol Community Health 2003 Dec;57(12):993.

6. Smith JC, Mercy JA, Conn JM. Marital status and the risk of suicide. Am J Public Health. 1988 Jan;78(1):78-80.

7. Grujić V. Adult population health status, health needs and health care utilisation in Serbia. Glasnik instituta za zaštitu zdravlja Srbije. 2003;(12):26-9. (In Serbian.)

8. Marcikić M, Ugljarević M, Dijanić T, Dumencić B, Pozgain I. Epidemiological features of suicides in Osijek County, Croatia, from 1986 to 2000. Coll Antropol. 2003;27 Suppl 1:101-10.

9. National Institute of Mental Health. Frequently asked questions about suicide. Bethesda: NIMH Public Inquiries; 2000.

10. Myrphy GE. Why women are less likely that men to commit suicide. Compr Psychiatry. 1998 Jul-Aug;39(4):165-75.

11. Durkheim E. The suicide. Beograd: BIGZ; 1997.

12. Qin P, Agerbo E, Westergård-Nielsen N, Eriksson T, Mortensen PB Gender differences in risk factors for suicide in Denmark. Br J Psychiatry. 2000 Dec; $177: 546-50$

13. Hawton K. Sex and suicide. Gender differences in suicidal behaviour. $\mathrm{Br}$ J Psychiatry. 2000 Dec;177:484-5.

14. Hawton K. By their own young hand. BMJ. 1992 Apr 18;304(6833):1000.

15. Kelly S, Bunting J. Trends in suicide in England and Wales, 1982-96. Popul Trends. 1998;(92):29-41.

16. Hawton K. Why has suicide increased in young males? Crisis 1998;19(3):119-24.

17. World Health Organization. Suicide prevention in Europe. The WHO European monitoring survey on national suicide prevention programmes and strategies. Copenhagen: WHO Regional Office for Europe; 2002.

18. Nikolić D, Dimitrijević D. Suicides in the SR Yugoslavia. Belgrade: Federal Center for Health Protection and Promotion; 1995.

19. Petrovich B, Cvetkovich M, Tiodorovich B, et al. Epidemiological characteristics of females suicides in the South-East part of Serbia. Acta Med Medianae. 1997;37(2):23-33.

20. Petrovich B, Kocich B, Cvetkovich M. Suicide and the other violent deaths in the Region of Nis in 1987. Preventive medicine days, Nis. Abstract book. Nis: 1987.

21. Petrovich B, Cvetkovich M, Tiodorovich B, et al. Epidemiological investigation of suicides in the South-East part of Serbia. Acta Med Medianae. 1993;33(3):87-96.

22. Petrovich B, Tiodorovich B, Kocich B, Cvetkovich M, Blagojevich L. Influence of socio-economic crisis on epidemiological characteristic of suicide in the region of Nis (southeastern part of Serbia, Yugoslavia). Eur J Epidemiol. 2001;17(2):183-7.

23. 23. Cheng AT, Chen TH, Chen CC, Jenkins R. Psychosocial and psychiatric risk factors for suicide. Case-control psychological autopsy study. Br J Psychiatry. 2000 Oct; 177:360-5.

24. Charlton J. Trends and patterns in suicide in England and Wales. Int J Epidemiol. 1995;24 Suppl 1:S45-52.

25. Heikkinen ME, Isometsä ET, Marttunen MJ, Aro HM, Lonnqvist JK. Social factors in suicide. Br J Psychiatry. 1995 Dec;167(6):747-53.

26. Schapira K, Linsley KR, Linsley A, Kelly TP, Kay DW. Relationship of suicide rates to social factors and availability of lethal methods: comparison of suicide in Newcastle upon Tyne 1961-1965 and 1985-1994. Br J Psychiatry. 2001 May; 178:458-64.

27. Kposowa AJ. Marital status and suicide in the National Longitudinal Mortality Study. J Epidemiol Community Health. 2000 Apr;54(4):254-61.

28. Luoma JB, Pearson JL. Suicide and marital status in the United States, 1991-1996: is widowhood a risk factor? Am J Public Health. 2002 Sep;92(9):1518-22.

29. Rocchi MB, Perlini C. Is the time of suicide a random choice? A new statistical perspective. Crisis. 2002;23(4):161-6 
30. Lester D, Frank ML. Sex differences in the seasonal distribution of suicides. Br J Psychiatry. 1988 Jul;153:115-7.

31. Micciolo R, Zimmermann-Tansella C, Williams P, Tansella M. Seasonal variation in suicide: is there a sex difference? Psychol Med. 1989 Feb;19(1):199-203.
32. Yip PS, Chao A, Ho TP. A re-examination of seasonal variation in suicides in Australia and New Zealand. J Affect Disord. 1998 Jan;47(1-3):141-50. Erratum in: J Affect Disord 2001 Mar;63(1-3):257.

Received April 2, 2008 Accepted in revised form August 22, 2008 